\section{MRI in acute Wernicke's encephalopathy}

W.D. Watson, MD, PhD, A. Verma, MD, PhD, M.J. Lenart, MD, T.M. Quast, MD, S.J. Gauerke, and G.J. McKenna, MD, Bethesda, $M D$

A 26-year-old woman presented with a 4-day history of progressive lateral ophthalmoplegia, inability to stand, gait ataxia, apathy, and confusion after 3 months of intractable postgastroplasty hyperemesis. ${ }^{1}$ The diagnosis of acute Wernicke encephalopathy was consistent with characteristic changes seen on her admission MRI (figure 1, A and B). ${ }^{2}$ Three hours after initiating thiamine, her lateral gaze returned, Romberg test was negative, and cognition improved dramatically. Her clinical improvement was correlated with normalization of hyperintense T2 MRI signals 5 days later (figure 1, C and D). This dramatic turnaround underscores the necessity of thiamine in acute Wernicke encephalopathy.

1. Skeen MB. Neurologic manifestations of gastrointestinal disease. Neurol Clin 2002;20:195-225, vii.

2. Murata T, Fujito T, Kimura H, et al. Serial MRI and (1)H-MRS of Wernicke's encephalopathy: report of a case with remarkable cerebellar lesions on MRI. Psychiatry Res 2001;108:49-55.

Address correspondence and reprint requests to Dr. William Watson, Department of Neurology, National Naval Medical Center, 8901 Wisconsin Ave., Bethesda, MD 20889-5600; e-mail: wdwatson@Bethesda.med.navy.mil
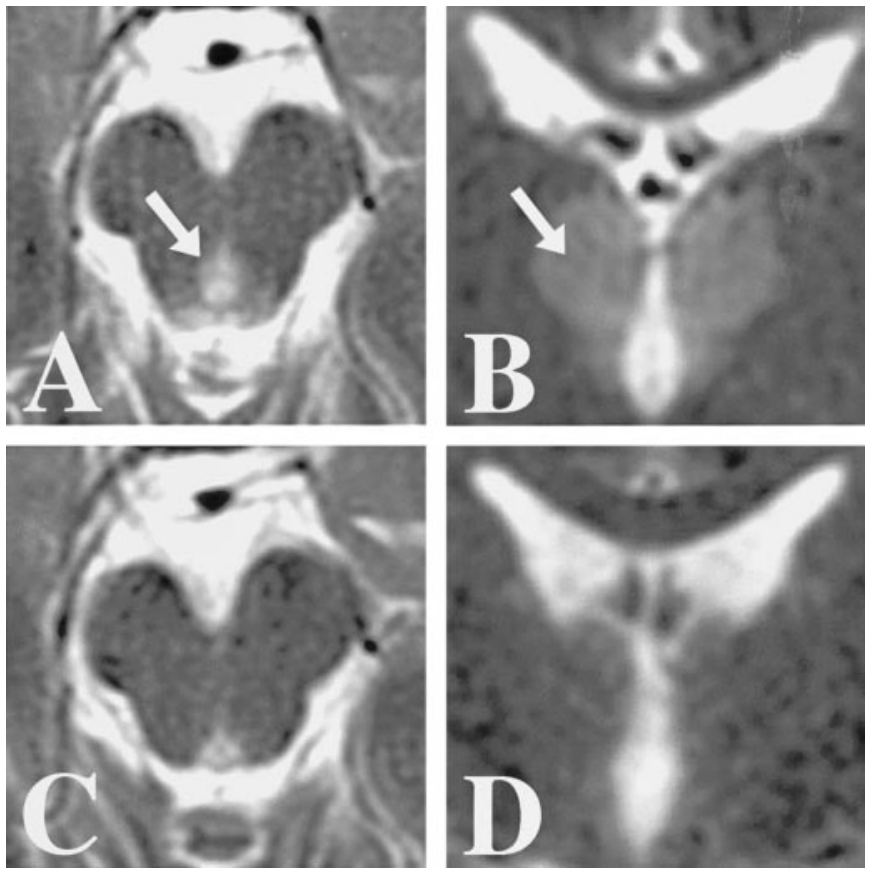

Figure. Rapid clearing of MRI signals in Wernicke encephalopathy. T2-weighted MR images at the time of admission show abnormal hyperintense signal (arrows) in the periaqueductal gray region (A, axial view) and dorsomedial thalami (B, coronal view), which cleared after 5 days of thiamine (100 $\mathrm{mg} I V)$ treatment $(C, D)$. 


\title{
Neurology
}

\author{
MRI in acute Wernicke's encephalopathy \\ W.D. Watson, A. Verma, M.J. Lenart, et al. \\ Neurology 2003;61;527 \\ DOI 10.1212/WNL.61.4.527
}

This information is current as of August 25, 2003

\section{Updated Information \& Services}

References

Citations

Subspecialty Collections

Permissions \& Licensing

Reprints including high resolution figures, can be found at: http://n.neurology.org/content/61/4/527.full

This article cites 2 articles, 0 of which you can access for free at: http://n.neurology.org/content/61/4/527.full\#ref-list-1

This article has been cited by 2 HighWire-hosted articles: http://n.neurology.org/content/61/4/527.full\#\#otherarticles

This article, along with others on similar topics, appears in the following collection(s):

MRI

http://n.neurology.org/cgi/collection/mri

Nutritional

http://n.neurology.org/cgi/collection/nutritional

Information about reproducing this article in parts (figures,tables) or in its entirety can be found online at:

http://www.neurology.org/about/about_the_journal\#permissions

Information about ordering reprints can be found online:

http://n.neurology.org/subscribers/advertise

Neurology ${ }^{\circledR}$ is the official journal of the American Academy of Neurology. Published continuously since 1951, it is now a weekly with 48 issues per year. Copyright . All rights reserved. Print ISSN: 0028-3878. Online ISSN: 1526-632X.

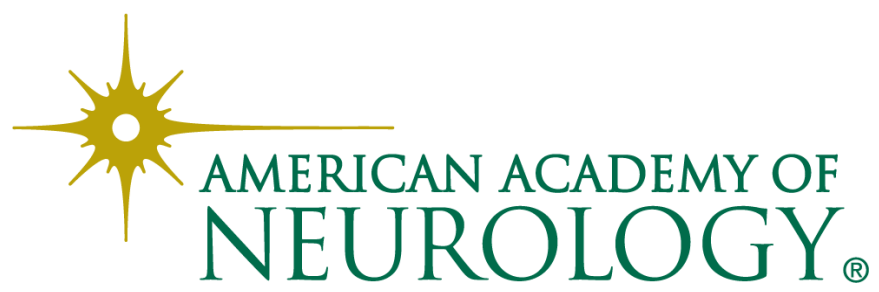

